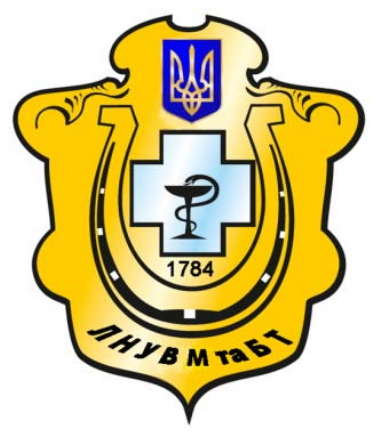

Науковий вісник Львівського національного університету ветеринарної медицини та біотехнологій імені С.3. Гжицького

Scientific Messenger of Lviv National University of Veterinary Medicine and Biotechnologies named after S.Z. Gzhytskyj

doi:10.15421/nvlvet7310

ISSN 2518-7554 print

ISSN 2518-1327 online

$\underline{\text { http://nvlvet.com.ua/ }}$

\title{
Гематологічні і біохімічні показники крові собак за умов застосування «Неоверму» та протекторів-антитоксикантів
}

\author{
I.О. Жукова, І.О. Костюк, Ю.С. Світлична-Кулак \\ patfiz@zoovet.kh.ua
}

Харківська державна зооветеринарна академія,

вул. Академічна, 10, смт. Мала Данилівка, Дергачівський район, Харківська обл., 62341, Україна

\begin{abstract}
У статті наведені дані щзодо впливу на організм собак антигельмінтного та імуномоделюючого препарату «Неоверм» за умов введення його в шлунок тварин протягом трьох діб, та результати його застосування в комбінації з препаратами, що містять антиоксидантні і мембраностабілізуючі речовини. Для захисту організму від токсичної дї «Неоверму» використовували препарати за двома схемами: «Е-Селен» $i$ «Квериетин», фосфоліпідний гепатопротектор «Лесфаль» $i$ «зелена гречка» (добавка в корм меленого необробленого зерна гречки як природного джерела квериетину). Порівняння проводили з контрольною групою та групою, яка отримувала тільки «Неоверм». Встановлено, шэо використання «Неоверму» собакам як на 7, так і на 14 добу, мало негативний вплив на гематологічні показники та активність ферментів крові, які відображають функиіональний стан печінки. Зокрема встановлено зниження кількості еритроиитів та рівня гемоглобіну, а також значне підвищення активності діагностичних ферментів: аланінової (АЛТ), аспарагінової (АСТ), гаммаглутамілової (ГГТ) трансфераз та лужної фосфатази (ЛФ). Запропоновані обидві схеми корекиії токсичного впливу препарату «Неоверм» у собак призводило до відновлення ендогенних антитоксичних ресурсів, тобто до поступової нормалізації гематологічних показників та активності індикаторних ферментів крові (зниженню активності АСТ, АЛТ, ГГТ, ЛФ $і$ ЛДГ та нормалізації кількості еритроцитів та гемоглобіну), щъо є підставою для використання циих препаратів у якості протекторів-антитоксикантів за умов застосування «Неоверму».

Ключові слова: Неоверм, собаки, Е-селен, Квериетин, Лесфаль, аланінамінотрансфераза, аспартатамінотрансфераза, гаммаглутамілтрансфераза, необроблене зерно гречки, зелена гречка, лужна фосфатаза.
\end{abstract}

\section{Гематологические и биохимические показатели крови собак при применении «Неоверма» и протекторов-антитоксикантов}

\author{
И.А. Жукова, И.А. Костюк, Ю.С. Светличная-Кулак \\ patfiz@zoovet.kh.ua
}

Харьковская государственная зооветеринарная академия,

ул. Академическая, 10, пгт. Малая Даниловка, Дергачевский район, Харьковская обл., 62341, Украина

\begin{abstract}
У статье приведены данные о влиянии на организм собак антигельминтного и иммуномоделирующего препарата «Неоверм» при условии введения его в желудок животных на протяжении трёх суток, и результаты его применения в комбинации с препаратами, которые содержат антиоксидантные и мембраностабилизирующие вещества. Для защиты организма от токсического воздействия «Неоверма» использовали препараты по двум схемам: «Е-Селен» и «Квериетин», фосфолипидный гепатопротектор «Лесфаль» и «зеленая гречиха» (добавка в корм дробленого необработанного зерна гречихи как природного источника квериетина). Сравнения проводили с контрольной группою и группой, которая получала только «Неоверм». Установлено, что использование «Неоверма» собакам как на 7, так и на 14 сутки, имело негативное влияние на гематологические показатели и активность ферментов крови, которые отражают функциональное состояние печени. Это отмечено снижением количества эритроцитов и уровня гемоглобина, а также значительным повышением активно-
\end{abstract}

\section{Citation:}

Zhukova, I.O., Kostyuk, I.O., Svitlychna-Kulak, Yu.S. (2017). Hematological and biochemical blood indices of dogs when using «Neoverm» and protectors-antioxidants. Scientific Messenger LNUVMBT named after S.Z. Gzhytskyj, 19(73), 46-49. 
сти диагностических ферментов: аланиновой (АЛТ), аспарагиновой (АСТ), гаммаглутамиловой (ГГТ) трансфераз и щзелочной фосфатазы (ЛФ). Обе предложенные схемы коррекции токсичного влияния препарата «Неоверм» у собак приводило к восстановлению эндогенных антитоксических ресурсов, то есть к постепенной нормализации гематологических показателей и активности индикаторных ферментов крови (снижению активности АСТ, АЛТ, ГГТ, ЛФ, ЛДГ и нормализации количества эритроцитов и гемоглобина), что является основанием для использования этих препаратов в качестве протекторов-антитоксикантов при условии применения «Неоверма».

Ключевые слова: Неоверм, собаки, Е-селен, Квериетин, Лесфаль, необработанное зерно гречихи, «зеленая гречиха», аланинаминотрансфераза, аспартатаминотрансфераза, гаммаглутамилтрансфераза, шелочная фосфатаза.

\title{
Hematological and biochemical blood indices of dogs when using «Neoverm» and protectors-antioxidants
}

\author{
I.O. Zhukova, I.O. Kostyuk, Yu.S. Svitlychna-Kulak \\ patfiz@zoovet.kh.ua
}

\author{
Kharkov state zooveterinary academy, \\ Akademichna Str., 1, Mala Danylivka, Kharkiv region, Dergachi district, 62341, Ukraine
}

\begin{abstract}
The article presents the data on the effect of antihelmintic and imunomodulating drug «Neoverm» on the dogs' body when the drug was administered into the stomach of the animals within three days and the results of its application in the combination with the drugs that contain antioxidant and membrane stabilizing substances. To protect the body from toxic action of «Neoverm» the drugs were used under two schemes: «E-Selenium» and «Quercetin», phospholipid hepaprotector "Lesphal» and "green buckwheat» (a feed additive - pre-ground raw buckwheat as a natural source of quercetin). The result a were compared with the control group and the group that received only "Neoverm». It has been found out that the use of «Neoverm» for the dogs both on the 7th and 14th days had a negative impact on the hematological parameters and the activity of blood enzymes that reflects the functional state of the liver. In particular, the reduction in the number of erythrocytes and the level of hemoglobin as well as the significant increase in the activity of diagnostic enzymes: alanine (ALT), asparagine (AST), gammaglutamyl (GGT) transferases and alkaline phosphatase $(A L P)$ have been revealed. The proposed schemes to correct the toxic effect of the drug "Neoverm» in dogs led to the restoration of endogenous antitoxic resources, that is, to a gradual normalization of hematological parameters and the activity of indicatory enzymes of blood (the decrease in the activity of AST, ALT, GGT, ALP and LDH and the normalization of the number of red blood cells and hemoglobin) and that is the basis for the use of the above drugs as protectors-antioxidants when «Neoverm» is used.

Key words: Neoverm, dogs, E-Selenium, Quercetin, Lesphal, alanine aminotransferase, aspartate aminotransferase, alkaline phosphatase,gammaglutamyltransferase, raw buckwheat grain, buckwheat green.
\end{abstract}

\section{Ветуп}

Однією $з$ проблем протипаразитарних заходів є висока пристосовність паразитів до екологічних умов, наявність механізмів адаптації щодо лікарських засобів, які застосовуються у практиці ветеринарної медицини. Досить перспективними у цьому напрямку є біопестициди, похідні авермектинів (Berezovskyi, 2000; Tishyn, 2015). Неоверм - препарат, який відноситься до цієї групи 3 основною діючою речовиною івермектином (суміш гідрованих авермектинів $\mathrm{B}_{1 \mathrm{a}} \mathrm{i}$ $\left.\mathrm{B}_{1 \mathrm{~B}}\right)$, у дозі $\left.10 \mathrm{мг} / 100 \mathrm{~cm}^{3}\right)$. Це новий, розроблений в Україні лікарський препарат широкого спектру дії, для профілактики та лікування свійських, домашніх тварин та птиці, що містить групи сполук, які продукуються грунтовими мікроорганізмами Streptomyces avermitilis, i має не тільки протипаразитарну, але й імуностимулюючу дію.

Однак, окрім терапевтичної протипаразитарної активності «Неоверм», за передозування, може несприятливо впливати на організм тварин і викликати клінічні ознаки отруєння і патологічні зміни в органах i системах. Для усунення цього ефекту, актуальним $є$ розробка методів і засобів корекції токсичного впливу на організм ксенобіотиків, для чого разом з засобами для дегельмінтизації застосовують різні комбінації антиоксидантів, гепато- і кардіопротекторів, вітамінних і мінеральних добавок тощо (Zhukova et al., 2016).
Метою роботи є встановлення особливостей токсичної дії «Неоверму», при застосуванні його собакам впродовж 3 діб, та корекція цього процесу за допомогою речовин 3 антиоксидантними і мембранопротекторними властивостями.

\section{Матеріал і методи досліджень}

У досліді використали 24 безпородні собаки, які належать Центру поводження з тваринами (м. Харків). Тварини віком 1-2 роки, масою 10-15 кг були розділені на чотири групи: I група - контрольна $(\mathrm{n}=6)$, II, III i IV - дослідні $(\mathrm{n}=18)$. Собаки II, III i IV груп отримували «Неоверм», щоденно впродовж трьох діб. Препарат вводили у шлунок по 0,6 мг/кг маси (1/10 ЛД 50 для щурів). Крім того, III дослідна група одержувала одноразово препарат «Е-селен» підшкірно у дозі $0,04 \mathrm{~cm}^{3}$ і «Кверцетин», перорально у дозі 100 мг/кг щодня. Тваринам IV групи застосовували гепатопротектор «Лесфаль», внутрішньовенно двічі з інтервалом у 7 днів у дозі $5 \mathrm{~cm}^{3}$ на 1 голову, а також додавали у корм порошок необробленого зерна гречки (як джерело кверцетину). Змелене зерно запарювали перед згодовуванням і додавали до корму в індивідуальній кількості 3 розрахунку 2 г на 10 кг маси тіла. Контрольній (І групі) «Неоверм» і препарати не задавали.

Клінічні і біохімічні дослідження крові проводили на 7 і 14 добу після введення «Неоверму». У тварин 
визначали кількість еритроцитів за допомогою калібрувальних графіків (Zabolockij and Poljakov, 1965), концентрацію гемоглобіну - гемоглобінцианідним методом (Mahan'ko and Gerasimenko, 1974; Kondrahin et al., 1985), кількість лейкоцитів підраховували у камері Горяєва.

У сироватці крові визначали активність ферментів: лактатдегідрогенази (ЛДГ, КФ 1.1.1.27) - за методом Савелла і Товарека (Kamyshnikov, 2003); лужної фосфатази (ЛФ) (К.Ф. 3.1.3.1.), аспартатамінотрансферази (АсАТ) (К.Ф.2.6.1.1.) та аланінамінотрансферази (АлАТ) (К.Ф.2.6.1.2.) за допомогою тест-наборів фірми «Фелісіт-Діагностика», м. Дніпро; гамма-глутамілтрансферази (ГГТ) (К.Ф.2.3.2.1) - за допомогою тест-реактивів фірми PLIVA-Lachema Diagnostika s.r.o., Чехія.

Показники активності ферментів розраховували за даними спектрофотометричних досліджень за кольоровими реакціями. Результати обробляли статистично
3 використанням програм Microsoft Excel, вірогідність отриманих даних оцінювали за критерієм Ст'юдента.

\section{Результати та їх обговорення}

Протягом досліду у тварин не відмічено клінічних ознак отруєння. Встановлено, що на 7 добу від початку введення «Неоверму» у крові собак II дослідної групи відмічене зниження кількості еритроцитів на $29,6 \%$, а через 14 діб - на 28,4\% (P $\leq 0,05)$ по відношенню до контролю. При додаванні до раціону собак «Кверцетину» i «Е-селену» (III група) та комбінації «Неоверм» + «зелена гречка» + «Лесфаль» (IV група) на 7 і 14 добу дослідження різниці у кількості еритроцитів по відношенню до контролю не відмічалось, але в порівнянні з групою, яка одержувала тільки «Неоверм» відмічено підвищення цього показника відповідно на 32,8-34,6\% на 7 добу та 24,6-25,8\% на 14 добу досліджень (табл. 1).

Таблиия 1

Гематологічні і біохімічні показники крові собак за введення «Неоверму», «Е-селену», «Лесфалю» і додавання до раціону «зеленої гречки» $(\mathrm{M} \pm \mathrm{m} ; \mathbf{n}=\mathbf{5})$

\begin{tabular}{|c|c|c|}
\hline \multirow{2}{*}{ Групи тварин } & \multicolumn{2}{|c|}{ Строки дослідження, доба } \\
\hline & 7 & 14 \\
\hline \multicolumn{3}{|c|}{ Кількість еритроцитів, Т/дм ${ }^{3}$} \\
\hline I - Контроль & $5,21 \pm 0,1$ & $5,33 \pm 0,4$ \\
\hline II - «Неоверм» & $4,02 \pm 0,6^{1}$ & $4,15 \pm 0,41^{1}$ \\
\hline III- «Неоверм»+ «Кверцетин»+ «Е-селен» & $5,34 \pm 0,12^{2}$ & $5,17 \pm 1,40^{2}$ \\
\hline IV -«Неоверм»+ «зелена гречка» + «Лесфаль» & $5,41 \pm 0,11^{2}$ & $5,22 \pm 0,4^{2}$ \\
\hline \multicolumn{3}{|c|}{ Концентрація гемоглобіну, г/дм ${ }^{3}$} \\
\hline I - Контроль & $127,2 \pm 6,9$ & $134,7 \pm 7,2$ \\
\hline II - «Неоверм» & $96,4 \pm 2,6^{1}$ & $101,3 \pm 9,0^{1}$ \\
\hline III - «Неоверм»+ «Кверцетин»+ «Е-селен» & $120,6 \pm 2,6^{4}$ & $127,0 \pm 10,2^{4}$ \\
\hline IV -«Неоверм»+ «зелена гречка» + «Лесфаль» & $130,4 \pm 3,3^{4}$ & $129,2 \pm 2,2^{4}$ \\
\hline \multicolumn{3}{|c|}{ Кількість лейкоцитів, Г/дм ${ }^{3}$} \\
\hline I- Контроль & $8,7 \pm 0,4$ & $9,2 \pm 0,3$ \\
\hline II - «Неоверм» & $9,5 \pm 0,2$ & $9,7 \pm 0,41$ \\
\hline III- «Неоверм»+ «Кверцетин»+ «Е-селен» & $9,2 \pm 0,3$ & $8,7 \pm 0,34$ \\
\hline IV -«Неоверм»+ «зелена гречка» + «Лесфаль» & $8,8 \pm 0,28$ & $9,3 \pm 0,41$ \\
\hline \multicolumn{3}{|c|}{ Активність ЛФ, Од/дм ${ }^{3}$} \\
\hline I- Контроль & $69,7 \pm 3,4$ & $62,3 \pm 3,1$ \\
\hline II - «Неоверм» & $229,4 \pm 9,6^{3}$ & $238,3 \pm 11,0^{3}$ \\
\hline III- «Неоверм»+ «Кверцетин»+ «Е-селен» & $138,4 \pm 2,6^{2,4}$ & $124,8 \pm 9,3^{2,4}$ \\
\hline IV -«Неоверм»+ «зелена гречка» + «Лесфаль» & $122,4 \pm 3,3^{1,2}$ & $120,2 \pm 8,2^{1,2}$ \\
\hline \multicolumn{3}{|c|}{ Активність АлАТ, Од/дм ${ }^{3}$} \\
\hline I - Контроль & $21,0 \pm 0,3$ & $27,3 \pm 0,2$ \\
\hline II - «Неоверм» & $36,2 \pm 0,8^{3}$ & $51,6 \pm 2,2^{3}$ \\
\hline III - «Неоверм» + «Кверцетин»+ «Е-селен» & $24,4 \pm 0,7^{1}$ & $29,4 \pm 0,7^{1}$ \\
\hline IV -«Неоверм»+ «зелена гречка» + «Лесфаль» & $25,7 \pm 0,11^{1}$ & $30,6 \pm 0,5$ \\
\hline \multicolumn{3}{|c|}{ Активність АсАТ, Од/дм ${ }^{3}$} \\
\hline I - Контроль & $13,0 \pm 0,3$ & $16,3 \pm 0,2$ \\
\hline II - «Неоверм» & $25,2 \pm 0,8^{3}$ & $29,6 \pm 2,2^{3}$ \\
\hline III - «Неоверм»+«Кверцетин»+«Е-селен» & $14,4 \pm 0,7^{4}$ & $20,8 \pm 0,7^{4}$ \\
\hline IV -«Неоверм»+ «зелена гречка» + «Лесфаль» & $15,6 \pm 0,3^{4}$ & $19,3 \pm 0,5^{4}$ \\
\hline \multicolumn{3}{|c|}{ Активність ГГТ, Од/дм ${ }^{3}$} \\
\hline I - Контроль & $1,3 \pm 0,1$ & $1,4 \pm 0,08$ \\
\hline II - «Неоверм» & $2,1 \pm 0,8^{3}$ & $1,9 \pm 2,2^{1}$ \\
\hline III - «Неоверм» +«Кверцетин»+ «Е-селен» & $1,5 \pm 0,072^{2}$ & $1,6 \pm 0,1^{2}$ \\
\hline IV -〈Неоверм» + «зелена гречка» + «Лесфаль» & $1,6 \pm 0,1^{2}$ & $1,5 \pm 0,5^{2}$ \\
\hline
\end{tabular}

Примітки: ${ }^{1}$ - різниця значень вірогідна за $(\mathrm{P} \leq 0,05)$ відносно контролю, ${ }^{2}-$ за $(\mathrm{P} \leq 0,05)$ відносно значень II дослідної групи, ${ }^{3}-$ за $(\mathrm{P} \leq 0,01)$ відносно значень у контролі; ${ }^{4}-$ за $(\mathrm{P} \leq 0,01)$ відносно значень у II дослідній групі тварин 
Аналогічні зміни відмічені щодо концентрації гемоглобіну, а саме, зниження вмісту цього показника в порівнянні з контролем у II групі на $32,0 \%$ на 7 добу і на 33,0\% на 14 добу досліду. У III і IV групі цей показник був нижчим за контроль у межах 4-6\%, але вищим у порівнянні з II групою на 24,5-25,4\% на 7 добу і на $24,6-40,3 \%(\mathrm{P} \leq 0,01)$ відповідно.

Дослідження вмісту лейкоцитів у крові собак не виявило суттєвої різниці як у дослідних, так і у контрольній групах тварин і він знаходився у межах фізіологічної норми.

За період досліду реєстрували підвищення активності лужної фосфатази у II групі тварин, що одержувала тільки «Неоверм» у 3,3 рази на 7 і у 3,8 рази - на 14 добу (P $\leq 0,01)$. Показники активності цього ферменту також були вищими за контроль у III групі на $98,0 \%$ - на 7 добу і у 2 рази на 14 добу досліду та у IV групі - на 75,6\% і 88,1\% відповідно.

У порівнянні з ІІ групою тварин активність ЛФ на 7 і 14 добу була нижчою у III групі на 65,7-90,9\% і у IV - на 87,4-97,8\% (P $\leq$ 0,05) відповідно.

На 7 і 14 добу досліджень (табл. 1) у II, III, IV групах собак відмічено збільшення по відношенню до контролю активності АЛТ на 72,4-89,0\% (P $\leq 0,01)$, $16,2-7,7 \%$ і 22,4-12,1\% (P $\leq 0,05)$, відповідно та активності АСТ на 93,8-81,6\% ( $\mathrm{P} \leq 0,01), 10,8-27,6 \%$ і 9,8-8,4\% відповідно, але у порівнянні з II групою собак активність АСТ на 7 і 14 добу була також нижчою у III групі на 75,0-43,3\% і у IV - на 61,5-53,4\% $(\mathrm{P} \leq 0,05)$ відповідно.

Схожі зміни помічені і у показниках активності гамма-глутамілтрансферази. Так, у порівнянні з контролем відмічено підвищення активності ГГТ у групі тварин, що одержувала тільки «Неоверм» (II) на $61,5 \%$, ( $\mathrm{P} \leq 0,01)$ на 7 добу і на $35,7 \%(\mathrm{P} \leq 0,05)-$ на 14. У порівнянні з ІІ дослідною групою активність цього ферменту була нижчою у III групі на 7 і 14 добу досліджень на 40,0-18,8\% і у IV - на 31,3-26,7\% $(\mathrm{P} \leq 0,05)$ відповідно.

В цілому можна зазначити, що активність всіх досліджуваних індикаторних ферментів за умов застосування «Неоверму» в усіх групах перевищувала контрольні показники і на 7, і на 14 добу досліду, але у III i IV групах, використання препаратів антиоксидантної дії і додавання меленого зерна гречки у корм, призвело до зниження активності АЛТ, АСТ, ЛФ і ГГТ.

Такі зміни активності ферментів відображають покращення функціонального стану печінки і $є$ результатом протекторної мембранотропної дії антиоксидантів на клітини.

\section{Висновки}

1. За результатами досліджень встановлено, що «Неоверм» у досліджуваній дозі, спричиняє негативний вплив на гематологічні показники, можливо шляхом пригнічення еритропоезу, що супроводжується достовірним зниженням кількості еритроцитів і вмісту в них гемоглобіну.
2. За введення $з$ терапевтичною метою «Неоверму» відмічено підвищення активності ендогенних ферментів крові із групи трансфераз (АЛТ, АСТ, ГГТ) та лужної фосфатази, що свідчить про гепатотоксичний механізм впливу цього препарату на організм;

3. Застосування разом із «Неовермом» препаратів «Е-селен», «Кверцетин», «Лесфаль» та додавання у корм необробленого меленого зерна гречки дає ефект відновлення ендогенних антитоксичних ресурсів (зниження активності індикаторних ферментів печінки нормалізації кількості еритроцитів та гемоглобіну) крові собак і $є$ підставою для використання цих препаратів у спрямованій протекторній дії.

\section{Бібліографічні посилання}

Berezovskyi, A.V. (2000). Likoopirnist zooparazytiv ta deiaki shliakhy yii podolannia. Veterynarna medytsyna Ukrainy. 3, 33-34 (in Ukrainian).

Tishyn, O.L. (2015). Farmako-toksykodynamika kompleksnoho protyparazytarnoho preparatu na osnovi aversektynu S i klozantelu ta odyn iz shliakhiv zmenshennia yoho pobichnoho vplyvu: avtoref. dys. ... doktora veter. nauk, 40 (in Ukrainian).

Lystivka-vkladka dlia zastosuvannia neovermu. - TOV «AT Biofarm», 2013.(in Ukrainian).

Zhukova, I.O., Svitlychna-Kulak, Yu.S., Lonhus, N.I. (2016). Korektsiia stanu antyoksydantnoho zakhystu u sobak za otruiennia neovermom. Naukovyi visnyk LNUVMBT imeni S.Z Hzhytskoho. 18, 3(70), 95-99 (in Ukrainian).

Zabolockij, V.T., Poljakov, V.F. (1965). Metodika podscheta jeritrocitov na kolorimetre tipa FJeK-M. Tr. Vsesojuz. in-ta jeksperim. veterinarii. 31, 281-286 (in Russian).

Kondrahin, I.P., Kurilov, N.V., Malahov, A.G. (1985). Klinicheskaja laboratornaja diagnostika v veterinarii : spravochnoe izdanie. M.: Agropromizdat, 143-145 (in Russian).

Mahan'ko, A.V., Gerasimenko, V.G. (1974). Tablicy dlja opredelenija cvetnogo pokazatelja i soderzhanija gemoglobina $\mathrm{V}$ jeritrocite sel'skohozjajstvennyh zhivotnyh. K.: Urozhaj (in Russian).

Kamyshnikov, V.S. (2003). Kliniko-biohimicheskaja laboratornaja diagnostika : Spravochnik: V 2 t. Mn: Interpresservis, 1 (in Russian).

Metod vyznachennia aktyvnosti luzhnoi fosfatazy $u$ syrovattsi krovi ta tkanynakh : prospekt firmy «Filisit Diahnostyka» (Ukraina), 2 (in Ukrainian).

Vyznachennia aktyvnosti alanin- i aspartamaminotransferaz $\mathrm{u}$ syrovattsi krovi ta tkanynakh metodom AlAT-mikro ta AsAT-mikro : prospekt firmy «Filisit Diahnostyka» (Ukraina), 2 (in Ukrainian).

Metod vyznachennia aktyvnosti hammahlutamiltransferazy: prospekt firmy «PLIVA-Lachema Diagnostika» s.r.o. Karasek 1, 62133 Brno, CZ, 2 .(in Ukrainian).

Стаття надійшла до редакції 16.03.2017 